\title{
PERBAIKAN KUALITAS RENGGINANG UBI KAYU TANPA FERMENTASI
}

\author{
B. Budi Setiawati \\ Politeknik Pembangunan Pertanian Yogyakarta-Magelang \\ Jl. Kusumanegara No.2, Yogyakarta, 55167 \\ Email : bebes5617@gmail.com
}

\begin{abstract}
Cassava rengginang, a Javanese traditional snack food still shows cloudy white color and no or very slight expansion when fried that are considered as a problem of undesired quality. Additional fermentation process in its manifacturing seems to be able to solve the problem. Fermentation process applied to the cassava rengginang manufacturing will affect its quality, especially the crispness, expansion capacity and taste. The crispness would possibly bring about irritation to both the throat and tounge in a little bit longer and more consumption. Two factors possibly influencing the above problem are frequency of washing process and total amount of starch resulted from every washing process, are taken as treaments. Organoleptic evaluation involving tests on texture, aroma, taste, crispness and levels of consumer preferences is taken as a variable response. The experimental design consisting of once, twice, trhee times and without washing process and total amount of starch related to the frequencies of the washing process was conducted to seek the best combination of the treatments that was automatically resulting in the highest variable response.

Investigation tests, conducted on the fried non fermented cassava rengginang, show that the combination of three time washing process related to 244.38 grams cassava starch, 30.50 gram residue with 3 liters of water is significantly the best and prefered more than that of currently available in local markets.
\end{abstract}

Keywords : Non Fermented, Cassava Rengginang, The crispness, Taste and Expansion capacity

\section{PENDAHULUAN}

\section{Latar Belakang}

Sebagai negara berkembang, pengembangan usaha kecil dan menengah harus terus berjalan. Mengingat sebagian besar penduduk Indonesia bekerja di bidang pertanian dan dimana produk hasil pertanian juga melimpah, maka pengembangan pengolahan hasil pertanian dianggap penting untuk saat ini.

Diversifikasi pangan yang merupakan salah satu pengembangan pengolahan hasil pertaniancukuppotensialuntukmenggerakkan pengembangan usaha kecil dan menengah. Salah satu usaha diversifikasi pangan adalah teknologi pembuatan rengginang ubi kayu. Rengginang dapat dikategorikan sebagai kerupuk yang merupakan kelompok makanan ringan yang memiliki kandungan pati tinggi, dimana sebelum dikonsumsi atau digoreng terlebih dahulu. Salah satu cara alternatif untuk membuat rengginang ubi kayu adalah dengan perlakuan proses fermentasi.

\section{Rumusan Masalah}

Salah satu konsep penilaian makanan adalah penerimaan organoleptik yang meliputi aroma, rasa, tekstur. Pengolahan ubi kayu menjadi rengginang ubi kayu melalui beberapa tahapan, diantaranya pengukusan dan fermentasi. Rengginang dari ubi kayu mempunyai beberapa kelemahan, yaitu warna yang tidak cerah/tidak putih, dan tidak mengembang ketika digoreng. Sebagai upaya untuk memperbaiki kualitas tersebut maka ditambahkan proses fermentasi 
dalam pembuatannya. Rengginang ubi kayu yang dibuat dengan proses fermentasi akan berpengaruh terhadap kualitas, yaitu kerenyahan dan daya kembang. Namun, kerenyahan tersebut jika dikonsumsi lama dan banyak akan menimbulkan rasa sakit (iritasi) pada tenggorokan maupun lidah. Untuk itu diperlukan penelitan tentang perbaikan kualitas rengginang ubi kayu non fermented.

\section{TINJAUAN PUSTAKA}

Ubi kayu merupakan komoditas hasil pertanian yang memiliki potensi baik untuk dikembangkan menjadi berbagai produk olahan pangan, baik secara langsung dikonsumsi oleh rumah tangga ataupun menjadi bahan baku industri pangan. Pada dasarnya ubi kayu dapat diolah langsung dari bentuk segarnya (ubi kayu segar), maupun diproses terlebih dahulu menjadi berbagai produk antara (setengah jadi). Dalam bentuk bahan setengah jadi, ubi kayu diolah menjadi tepung tapioka, tepung singkong (casava), gaplek dan oyek. Bahanbahan tersebut, khususnya tepung tapioka, sebagian besar diserap oleh industri, untuk bahan baku berbagai produk olahan pangan maupun non pangan. (Anonim,2012)

Potensi ubi kayu di Indonesia sangat besar baik ditinjau dari sisi sumber bahan pangan utama karbohidrat setelah padi dan jagung, maupun sebagai bahan pakan dan bahan baku industri. Dilihat dari kontribusinya terhadap Produk Domestik Bruto (PDB), ubi kayu memberikan kontribusi tanaman pangan terbesar ketiga setelah padi dan jagung pada tahun 2003 sebesar Rp 6,1 triliun (hanya dari on farm).
Kontribusinya terhadap produksi ubi kayu dunia adalah sebesar 10 persen, dimana pada tahun 2002 produksinya sebesar 16.913.104 ton, tahun 2003 sebesar 18.523.810 ton, dan tahun 2004 sebesar 19.249.169 ton (Valerina, 2007).

\section{Rengginang}

Rengginan atau Rengginang adalah sejenis kerupuk yang terbuat dari nasi atau ketan yang dikeringkan lalu digoreng panas (deep-fry). Rengginang merupakan salah satu makanan tradisional yang sudah ada sejak jaman dulu namun sampai sekarang masih tetap eksis di pasaran. Rengginang pada umumnya terbuat dari beras ketan, namun saat ini sudah ada rengginang yang terbuat dari bahan baku ubi kayu (Anonim, 2011).

Rengginang ubi kayu adalah rengginang yang terbuat dari bahan baku ubi kayu. Pembuatan rengginang ubi kayu secara ringkas adalah sebagai berikut:

1. Pengupasan dan Pencucian.

Singkong dikupas dan dicuci bersih.

2. Pemarutan

Parut yang digunakan ada (dua) macam yaitu:

1) Parut manual, dilakukan secara tradisionaldengan memanfaatkan tenaga manusia sepenuhnya.

2) Parut semi mekanis, digerakkan dengan generator.

3. Pemerasan/ekstraksi

Hasil parutan dimasukkan kedalam bak untuk diambil acinya, proses ini dilakukan berulang-ulang supaya mendapatkan aci yang banyak. Pemerasan dapat dilakukan dengan 2 (dua) cara yaitu:

a) Pemerasan bubur ubikayu yang dilakukan dengan cara manual 
menggunakan kain saring. kemudian diremas sambil ditambahkan air dimana cairan yang diperoleh adalah pati yang ditampung di dalam ember.

b) Pemerasan bubur ubikayu dengan saringan goyang (sintrik). Bubur ubikayu diletakkan di atas saringan yang digerakkan dengan mesin. Pada saat saringan tersebut bergoyang, kemudian ditambahkan air melalui pipa berlubang. Pati yang dihasilkan ditampung dalam hak pengendapan.

4. Pengendapan

Pengendapan, yaitu proses mengendapkan air selama maksimal 4 jam, kemudian pisahkan air yang jernih dengan endapat aci sampai diperoleh aci.

5. Pencampuran.

Dalam membuat rengginang ubi kayu yang penting adalah mencampur antara ampas singkong dengan aci hasil endapan, kemudian dicampur bumbu-bumbu.

6. Pencetakan

Hasil dari pencampuran lalu digosokkan/ diparutkan pada parut dengan lubang besar sehingga membentuk butiranbutiran seperti beras, kemudian dicetak bulat-bulat seperti rengginang.

7. Pengukusan

Pengukusan rengginang adalah proses mengukus rengginang dalam cetakan selama 10 menit. Setelah dingin, kemudian dilepas dan dilakukan penjemuran dalam plat-plat/tampah.

8. Proses terakhir dalam membuat rengginang singkong adalah melakukan pengemasan jika rengginang tidak langsung dikonsumsi. Namun, jika akan dikonsumsi secara langsung, maka perlu menggorengnya dalam minyak yang cukup dan suhu tinggi agar rengginang dapat mengembang.

Bahan dasar rengginang ubi kayu adalah pati, kandungan amilopektin dalam pati sangat menentukan daya kembang rengginang. Semakin tinggi kandungan amilopektin pati maka rengginang yang dihasilkan akan mempunyai daya.

Salah satu cara memperbaiki kualitas rengginang ubi kayu adalah dengan memperbaiki proses produksi yaitu dengan cara proses non fermented, maksudnya merupakan metode pengendalian kualitas yang dilakukan pada proses pencucian dan pemerasan/ektraksi dalam tahap menghasilkan pati atau aci.

Metode proses non fermented merupakan salah satu perbaikan kualitas yang berdasarkan desain eksperimen dan bertujuan untuk mencari karakteristik kualitas pada produk rengginang ubi kayu yang dihasilkan.

Atribut kualitas rengginang ubi kayu yang menjadi pertimbangan konsumen dalam membeli produk adalah warna(kenampakan), cita rasa, aroma, kerenyahan dan daya kembang.

\section{Metode Penelitian}

1. Jumlah pencucian yang dilakukan $(1 \mathrm{x}$, 2x, dan 3x). Kontrol (tanpa pencucian).

$$
\begin{aligned}
& \mathrm{P} 0=\text { tanpa pencucian } \\
& \mathrm{P} 1=\text { pencucian } 1 \times(\mathrm{ltr}) \\
& \mathrm{P} 2=\text { pencucian } 2 \times(1 \mathrm{tr}) \\
& \mathrm{P} 3=\text { pencucian } 3 \times(\mathrm{ltr})
\end{aligned}
$$

2. Banyaknya aci yang dihasilkan dari setiap pencucian (gram). 


$$
\begin{array}{ll}
\mathrm{P} 0 & =>\mathrm{B} 0 \\
\mathrm{P} 1 & =>\mathrm{B} 1 \\
\mathrm{P} 2 & =>\mathrm{B} 2 \\
\mathrm{P} 3 & =>\mathrm{B} 3
\end{array}
$$

Sehingga kombinasi dari kedua perlakuan tersebut adalah :

1. $\mathrm{P} 0 \mathrm{~B} 0$

2. $\mathrm{P} 1 \mathrm{~B} 1$

3. $\mathrm{P} 2 \mathrm{~B} 2$

4. $\mathrm{P} 3 \mathrm{~B} 3$

\section{Prosedur Penelitian}

\section{Studi Pembuatan Rengginang Ubi Kayu}

Sebelum dilakukan penelitian di laboratorium, dilakukan studi pendahuluan terlebih dahulu, yang meliputi studi pustaka dan studi lapang. Studi pustaka dilakukan dengan mencari literatur baik berupa buku maupun teks pendukung yang berhubungan dengan pembuatan rengginang ubi kayu. Studi Lapang dilakukan dengan kunjungan ke masyarakat/petani pembuat rengginang ubi kayu yang ada di Kecamatan Pengasih,dan Kecamatan Kalibawang Kabupaten Kulon Progo serta Kecamatan Playen, Gunung Kidul.

\section{Pembuatan Rengginang Ubi Kayu}

Langkah pembuatan rengginang ubi kayu adalah seperti gambar berikut:

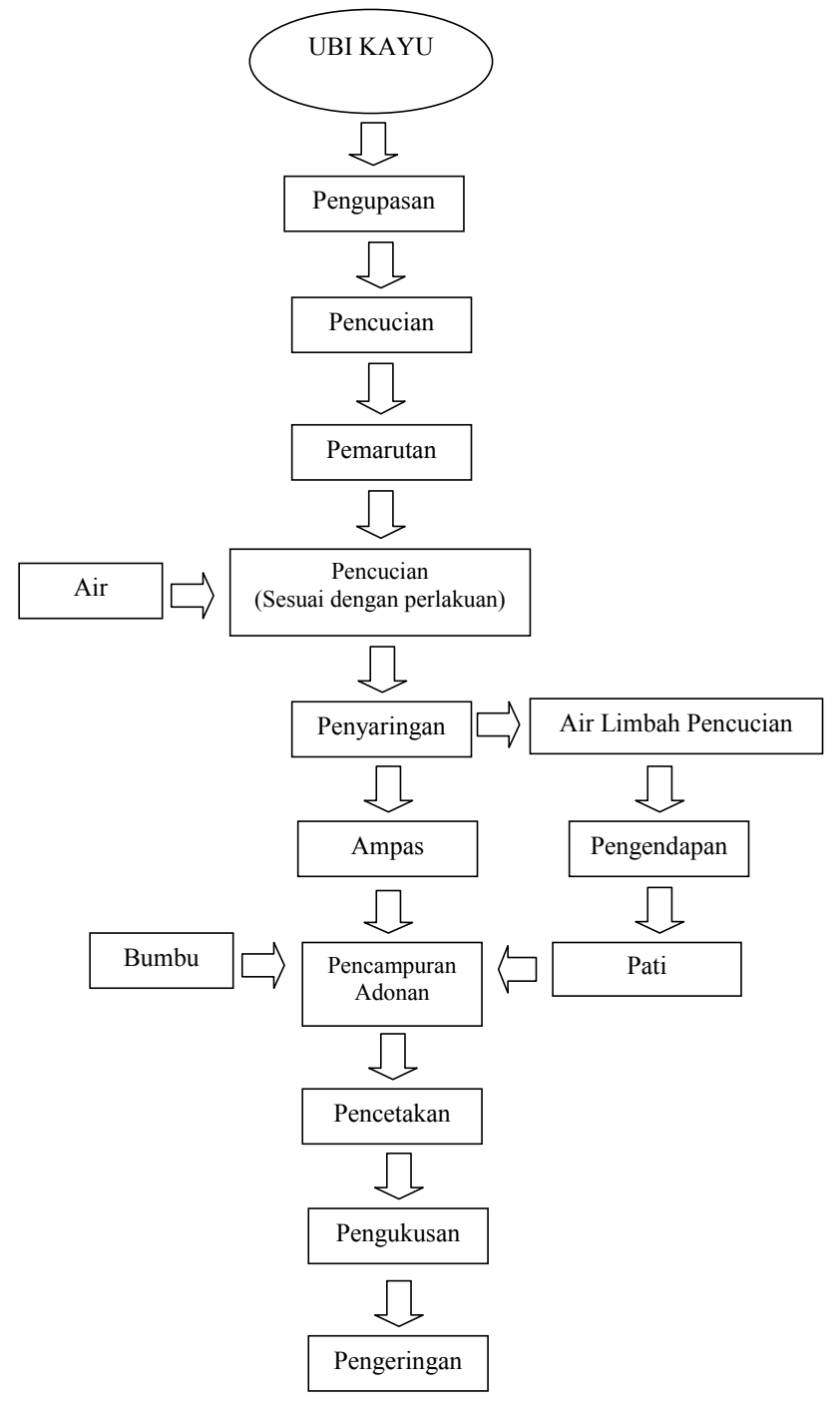

Gambar 1. Diagram Alir Pembuatan Rengginang Ubi Kayu Non Fermented 


\section{HASIL DAN PEMBAHASAN}

Rengginang ubikayu berkualitas tinggi apabila memiliki karakteristik kualitas, yaitu warna (kenampakan), citarasa, aroma, kerenyahan (daya patah), dan daya kembang. Penelitian ini dilakukan menggunakan rancangan non fermented untuk memperbaiki kualitas rengginang yaitu dengan perlakuan memperhatikan jumlah pencucian, jumlah aci yang dihasilkan dari setiap pencucian, berdasarkan hasil perhitungan :

\section{Tingkat Kesukaan Rengginang ubi kayu}

Tingkat kesukaan rengginang ubi kayu merupakan gambaran tentang kesukaan terhadap produk rengginang ubi kayu, yang diukur dengan menggunakan skala atau tingkatan. Untuk mengetahui tingkat kesukaan terhadap rengginang ubi kayu hasil penelitian dan rengginang ubi kayu yang sudah ada di peredaran, maka dilakukan uji organoleptik terhadap 35 panelis.

Berdasarkan pengalamannya dalam mengkonsumsi rengginang ubi kayu, ke 35 panelis dapat dikelompokan ke dalam dua kelompok, yaitu kelompok panelis yang sudah pernah mengkonsumsi rengginang ubi kayu dan kelompok rpanelis yang belum pernah mengkonsumsi rengginang ubi kayu.

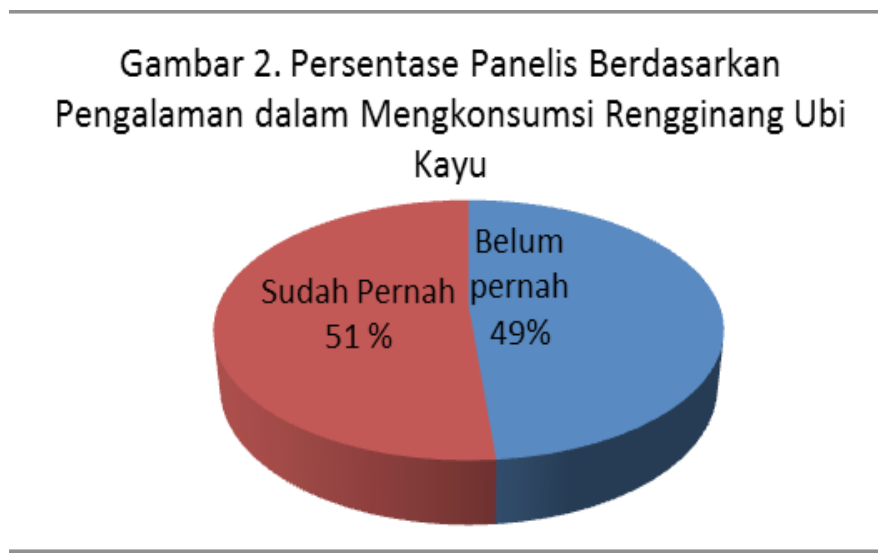

Dari gambar di atas terlihat bahwa $51 \%$ panelis sudah pernah mengkonsumsi rengginang ubi kayu, dan 49\% rpanelisn belum pernah mengkonsumsii rengginang ubi kayu. Artinya, prosentasi panelis yang sudah berpengalaman dalam mengkonsumsi rengginang ubi kayu lebih besar jika dibandingkan dengan yang belum berpengalaman. Dengan demikian diharapkan uji organoleptik dan uji preferensi konsumen yang dilakukan terhadap produk rengginang ubi kayu dapat memberikan hasil yang lebih baik. antar perlakuan, maka dilakukan pengkodean terhadap produk yang ada, pengkodean tersebut adalah sebagai berikut :

$\mathrm{R} 1$ = rengginang ubi kayu non fermented tanpa pencucian

$\mathrm{R} 2$ = rengginang ubi kayu non fermented $1 \mathrm{x}$ pencucian

$\mathrm{R} 3=$ rengginang ubi kayu non fermented $2 \mathrm{x}$ pencucian

$\mathrm{R} 4=$ rengginang ubi kayu non fermented $3 \mathrm{x}$ pencucian

$\mathrm{R} 5=$ rengginang ubi kayu yang ada diperedaran

Untuk membedakan produk rengginang 
Tingkat kesukaan rengginang ubi kayu mentah

- Warna

Warna rengginang ubi kayu di klasifikasikan ke dalam tiga kelompok, yaitu putih (3), buram (2) dan coklat (1).

Rengginang ubi kayu (R4) dengan 3 kali pencucian mempunyai nilai yang paling tinggi dibandingkan dengan rengginang ubi kayu yang tanpa pencucian, 1x pencucian, 2x pencucian maupun yang ada di peredaran. Ini menunjukkan bahwa proses perlakuan banyaknya pencucian berpengaruh terhadap warna dari rengginang ubi kayu non fermented. Semakin banyak pencucian dilakukan maka rengginang ubi kayu yang dihasilkan akan semakin putih. Warna R1 dan R5 mempunyai nilai yang lebih sedikit, karena warna R1 dan R5 lebih cenderung ke warna coklat

Hasil analisis perhitungan tentang warna dari rengginang ubi kayu di dapat bahwa nilai $\mathrm{F}$ hitung adalah 30,39 dan $\mathrm{F}$ tabel adalah 2,68. Nilai $\mathrm{F}$ hitung lebih besar dari $\mathrm{F}$ tabel, sehingga terdapat perbedaan yang nyata terhadap warna rengginang ubi kayu. Sedangkan dari hasil perhitungan terhadap tingkat kesukaan terhadap warna rengginang ubi kayu diperoleh nilai $\mathrm{F}$ hitung sebesar 17,17. Nilai $F$ hitung lebih besar dari F tabel $(17,17>2,68)$, sehingga terdapat perbedaan yang nyata terhadap kesukaan dari warna rengginang ubi kayu.

\section{- Aroma}

Aroma rengginang ubi kayu diukur secara organoleptik dengan menggunakan indera pembau. Aroma rengginang ubi kayu di klasifikasikan ke dalam tiga kelompok, yaitu Enak (3), Agak enak (2) dan tengik (1).

RengginangubikayuR3 mempunyai nilai paling bagus dibandingkan dengan R4, R1, R2 maupun R5. Rengginang ubi kayu di peredaran mempunyai aroma yang paling rendah dibandingkan dengan rengginang yang lain.

Hasil analisis perhitungan tentang aroma dari rengginang ubi kayu di dapat bahwa nilai $\mathrm{F}$ hitung adalah 16,29 , dan F tabel adalah 2,68. Nilai F hitung lebih besar dari $\mathrm{F}$ tabel, sehingga terdapat perbedaan yang nyata terhadap aroma dari rengginang ubi kayu. Sedangkan dari hasil perhitungan terhadap tingkat kesukaan terhadap aroma rengginang ubi kayu diperoleh nilai $\mathrm{F}$ hitung sebesar 8,370 . Nilai $F$ hitung lebih besar dari $F$ tabel $(8,370>2,68)$, sehingga terdapat perbedaan yang nyata terhadap kesukaan dari aroma rengginang ubi kayu.

\section{- Tekstur}

Tekstur produk rengginang diukur dan diamati kemudian dikelompokan ke dalam dua kelompok yaitu mudah patah (2) dan tidak mudah patah (1).

Rengginang ubi kayu R5 mempunyai tekstur yang paling mudah patah dibandingkan dengan R1, R2, R3 maupun R4. Hal ini dikarenakan R5 mempunyai tingkat ketebalan yang lebih tipis dibandingkan dengan yang lainnya. Namun setelah dilakukan analisis tekstur tersebut berbeda secara nyata. Hal ini ditunjukkan dengan nilai $\mathrm{F}$ hitung $>\mathrm{F}$ tabel $(3,827>2,68)$. Sedangkan untuk 
tingkat kesukaan terhadap tekstur rengginang ubi kayu berbeda secara nyata. Ini dibuktikan dengan nilai $\mathrm{F}$ hitung $>\mathrm{F}$ tabel $(4,77>2,68)$.

\section{Tingkat Kesukaan Rengginang Ubi Kayu Matang}

Penilaian terhadap produk rengginang ubi kayu matang dilakukan setelah rengginang ubi kayu mengalami proses pengolahan, yaitu proses penggorengan.

Penilaian terhadap produk matang meliputi rasa, kerenyahan dan daya kembang.

- Rasa

Penilaian terhadap rasa dikelompokan ke dalam dua kelompok, yaitu gurih (2) dan asam/tengik (1).

R3 mempunyai nilai tertinggi dibandingkan dengan R1, R2, R4 maupun R5. Rengginang ubi kayu yang ada di peredaran mempunyai nilai rata-rata yang paling rendah dibandingkan dengan rengginang ubi kayu yang lainnya. Dari hasil analisis terhadap rasa rengginang ubi kayu diperoleh nilai $\mathrm{F}$ hitung sebesar 2,12 , sehingga $\mathrm{F}$ hitung $<\mathrm{F}$ tabel $(2,12$ $<2,68$ ), ini menunjukkan tidak terdapat perbedaan yang nyata dari rasa rengginang ubi kayu. Sedangkan hasil analisis kesukaan terhadap rasa rengginang ubi kayu menunjukkan adanya perbedaan yang nyata terhadap rasa dari rengginang ubi kayu. Hal ini ditunjukkan dengan nilai F hitung $>$ F tabel $(2,806>2,68)$

\section{- Kerenyahan}

Penilaian terhadap kerenyahan dikelompokan ke dalam dua kelompok, yaitu renyah (2) dan tidak renyah (1).
R4 dengan R5 mempunyai nilai tertinggi dibandingkan dengan R1, R2, maupun R3. Dari hasil analisis terhadap kerenyahan rengginang ubi kayu diperoleh nilai $\mathrm{F}$ hitung sebesar 4,219, sehingga $\mathrm{F}$ hitung $>\mathrm{F}$ tabel $(4,219>$ 2,68), ini menunjukkan bahwa terdapat perbedaan yang nyata dari kerenyahan rengginang ubi kayu. Namun, hasil analisis terhadap tingkat kesukaan dari kerenyahan rengginang ubi kayu tidak berbeda secara nyata. Ini ditunjukkan dengan nilai $\mathrm{F}$ hitung $<\mathrm{F}$ tabel $(1,501<$ 2,68). Artinya tingkat kesukaan panelis terhadap kerenyahan rengginang ubi kayu baik R1, R2, R3, R4, maupun R5 tidak berbeda.

\section{- Daya Kembang}

Daya kembang dinilai berdasarkan besarnya kemampuan produk rengginang untuk mengembang ketika dilakukan penggorengan. Semakin besar ukuran rengginang setelah dilakukan penggorengan, maka dianggap rengginang tersebut mempunyai daya kembang yang semakin baik. Hasil uji organoleptik terhadap daya kembang rengginang dapat dilihat pada

R5 mempunyai nilai tertinggi dibandingkan dengan R1, R2, R3 maupun R4. R5 merupakan produk yang ada di peredaran, R5 mempunyai nilai daya kembang yang paling tinggi karena rengginang ini dibuat dengan proses fermentasi. Sedangkan daya kembang R1, R2, R3 dan R4 berbeda-beda nilainya, semakin banyak perlakuan pencucian yang dilakukan maka semakin tinggi nilai daya kembangnya. Dari hasil analisis 
terhadap daya kembang rengginang ubi kayu diperoleh nilai $\mathrm{F}$ hitung sebesar 36,422 sehingga $\mathrm{F}$ hitung $>\mathrm{F}$ tabel $(36,422>2,68)$, ini menunjukkan bahwa terdapat perbedaan yang nyata dari daya kembang rengginang ubi kayu. Hasil analisis terhadap tingkat kesukaan dari daya kembang rengginang ubi kayu berbeda secara nyata. Ini ditunjukkan dengan nilai $\mathrm{F}$ hitung $>\mathrm{F}$ tabel $(10,619>$ 2,68). Artinya tingkat kesukaan panelis terhadap daya kembang rengginang ubi kayu baik R1, R2, R3, R4, serta R5 berbeda.

Berdasarkan hasil organoleptik dapat dinyatakan bahwa produk rengginang ubi kayu yang paling disukai oleh adalah R4, yaitu rengginang ubi kayu non fermented dengan 3x pencucian (3 liter air, berat aci 244, 38 gram dan ampas 30,50 gram).

Berdasarkan hasil organoleptik dapat dinyatakan bahwa produk rengginang ubi kayu yang paling disukai oleh panelis adalah seperti pada gambar berikut :

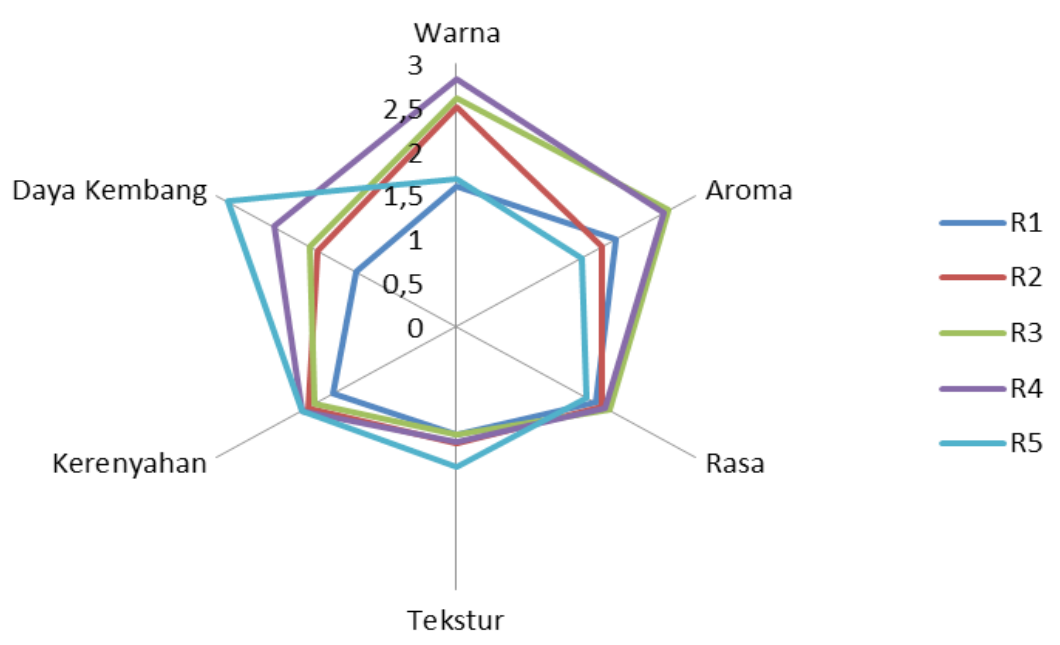

Gambar 3. Jaring Laba-Laba Hasil Uji Tingkat Kesukaan Rengginang Ubi Kayu Non

Fermentasi

\section{DAFTAR PUSTAKA}

Anonim, 2011. Rengginang Ubi, Penganan Biasa dari Bahan Tidak Biasa.

Diunduh dari http://epetani.deptan. go.id/budidaya/rengginang-ubipenganan-biasa-dari-bahan-tidakbiasa-3575 pada tanggal 12 Apri 2012.

Anonim, 2012. Materi Pelatihan Penganekaragaman Makanan Berbahan Baku Lokal. STPP Jurluhtan Yogyakarta dan LP2M STIA An Nur. Yogyakarta.
Achmad Suryana. 2005. Makalah Seminar : Kebijakan Ketahanan Pangan Nasional. di Faperta IPB. Bogor.

Cahyonohadi, Azwar, 2011. Studi pembuatan Rengginang Serbuk Ubi Kayu (Manihot Esculenta Crantz) dengan Perlakuan konsentrasi Tepung Tapioka, Universitas Jemberm Tawa Timur

Engel, James F. 1994. Perilaku Konsumen. Binarupa Aksara. Jakarta.

Kartika, B., Hastuti,P. dan Supartono,W. 1988. Pedoman Uji Inderawi Bahan Pangan. PAU Pangan dan Gizi UGM. Yogyakarta 
Rachman HPS dan Aryani, M. 2002. Ketahanan Pangan : Konsep, Pengukuran dan Strategi. FAE. Vol. 20 No 1.

Siagian, D. Dan Sugiarto. 2002. Metode Statistika Untuk Bisnis dan Ekonomi. PT. Gramedia Pustaka Utama. Jakarta.

Soetanto, E. 2001. Membuat patilo dan Kerupuk Ketela. Teknologi Tepatt Guna. Yogyakarta. Penerbit Kanisius.

Sucihatiningsih, dkk. 2009. Analisis Persepsi dan Preferensi Ibu Rumah Tangga Terhadap Produk pangan Olahan Berbasis Tepung Ubi Jalar dalam Meningkatkan Keanekaragaman Pangan, Fak. Ekonomi Universitas Naegeri Semarang.

Suprapti, M.L. 2005. Tepung Tapioka :
Pembuatan dan Pemanfaatannya. Kanisius. Yogyakarta

Valerina Darwis, 2009. Analisi Usaha Tani dan Pemasaran Ubi Kayu Serta Teknologi Pengolahan Tapioka di Kabupaten Pati, Jawa Tengah. Disampaikan dalam Seminar Nasional Peningkatan Daya Saing Agribisnis Berorientasi Kesejahteraan Petani di Bogor, Deptan.

Wibisono, Y. 2005. Metode Statistik. Gadjah Mada University Press. Yogyakarta.

Witono Tri, 2011. Antara Rengginang Singkong Bojonegoro Dan Pathilo Gunungkidul, diakses dari

http://www.triwitono.staff.ugm.ac.id/ ind ex.ph p ? o p t i o $\mathrm{n}=\mathrm{com}$ content\&view $=$ article $\& i d=52 \quad$ pada tanggal 20 April 2011 